\title{
Tingkat Pendidikan Ibu dengan Pemeriksaan Awal Kehamilan (K1) di Puskesmas Krebet Kecamatan Pilangkenceng Kabupaten Madiun
}

\author{
Mother's Education Level with First Antenatal Visit (K1) in Krebet Community Health Center Pilangkenceng \\ District Madiun \\ Dyah Permata Sari \\ Program Studi D3 Kebidanan \\ Politeknik Kesehatan Majapahit Mojokerto, Jawa Timur \\ *Corresponding author: dyahpermatasari86@yahoo.co.id
}

\begin{abstract}
ABSTRAK
Pelayanan antenatal care memainkan peranan yang penting dalam mencegah dan mendeteksi komplikasi obstetrik sedini yang mungkin serta ditangani pada tahapan awal untuk mendapatkan ibu dan bayi yang sehat. Tujuan penelitian ini untuk Mengetahui hubungan antara tingkat pendidikan ibu dengan pemeriksaan awal kehamilan (K1) di Puskesmas Krebet Pilangkenceng Madiun.

Jenis penelitian analitik korelasional menggunakan pendekatan cross sectional. Variabel penelitian tingkat pendidikan ibu sebagai variabel independent dan pemeriksaan awal kehamilan (K1) sebagai variabel dependent. Populasi penelitian seluruh ibu hamil di Puskesmas Krebet Pilangkenceng Madiun pada Bulan Januari - Agustus 2016 sebanyak 49. Sampel diambil dengan teknik simple random sampling sebanyak 43 responden pada tanggal 3 Oktober - 30 Desember 2016. Data dikumpulkan dalam bentuk data sekunder kemudian hasil pengumpulan data diuji dengan uji wilcoxon.

Hasil penelitian menunjukkan bahwa sebagian besar responden paling banyak pendidikan responden adalah menengah (SLTA) sebanyak 29 responden (67,4\%) dan kunjungan K1 Akses sebanyak 35 responden (81,4\%) dan kunjungan K1 murni sebanyak 8 responden (18,6\%).

Hasil statistic Wilcoxon Signed Rank pada program SPSS diperoleh hasil $\rho=0,042$. Jika $\alpha=0,05$ maka dapat disimpulkan $\rho<\alpha$ artinya $H_{0}$ ditolak berarti ada hubungan antar tingkat pendidikan dengan pemeriksaan awal kehamilan (K1).

Pada umumnya semakin tinggi pendidikan seseorang akan mempengaruhi kunjungan kehamilan yaitu responden yang berpendidikan tinggi cenderung melakukan kunjungan ANC K1 murni, sedangkan responden yang berpendidikan rendah cenderung memilih kunjungan ANC K1 akses. diharapkan ibu juga dapat meningkatkan informasi yang diperoleh tentang kunjungan ANC sehingga dapat melakukan kunjungan dengan lebih aktif dan dapat mendeteksi kelainan pada kehamilan secara dini.
\end{abstract}

Kata kunci : tingkat pendidikan, pemeriksaan kehamilan (k1)

\section{ABSTRACT}

Antenatal care $(A N C)$ services play an important role in preventing and detecting obstetric complications as early as possible and treated in the early stages to get healthy mother and baby. The purpose of this study is to know the relationship between the level of mother education with early pregnancy examination (K1) in Krebet Puskesmas Pilang kenceng Madiun.

The type of this study is correlational analytic using correlational crosssectional. The independent variable of this research was mother's education level and the dependent variable was early pregnancy examination (K1). The population of this study were all pregnant women in Krebet Puskesmas Pilangkenceng Madiun in January - August 2016 as many as 49 women. Samples were taken by simple random sampling technique as much as 43 respondents on 3 Oktober-30 December 2016. Data collected in the form of secondary data and then tested on data collection with Wilcoxon test.

The results showed that most respondents were graduated from senior high school as many as 29 respondents (67.4\%) and the respondent swho did K1 access visits as many as 35 respondents (81.4\%) and pure K1 visits by 8 respondents $(18.6 \%)$.

Results of the Wilcoxon Signed Rank statistic on SPSS results obtained $\rho=0.042$. If $\alpha=0.05$, which $\rho<\alpha$, it 
means that $H_{0}$ is rejected so it can be concluded that there is a relationship between level of education and early pregnancy examination (K1).

In general, the higher a person's education is the prenatal visit tend to visit pure K1, while the less educated respondents tend to choose K1 access visits. Hopefully mother can also increase the information obtained about the antenatal care (ANC) so they will make more active visit and can detect abnormalities in pregnancy earlier.

Keywords: education level, antenatal care

\section{PENDAHULUAN}

Pemeriksaan antenatal care adalah pemeriksaan yang dilakukan secara berkala terhadap ibu hamil untuk memeriksa ibu dan janin dengan upaya koreksi terhadap penyimpangan yang ditemukan. Kunjungan antenatal dilakukan sebanyak empat kali sepanjang periode kehamilan. Ibu hamil yang melaksanakan kunjungan antenatal care dapat memperoleh pelayanan 7T (timbang, tensi darah, tinggi fundus uteri, tetanus toxoid dan tablet Fe, tes PMS, Temu wicara) serta nasehat tentang kesehatan dan keluarga berencana yang meliputi hal-hal seperti perawatan diri selama hamil, kebutuhan makanan, penjelasan tentang kehamilan, persiapan persalinan, tanda dan bahaya pada kehamilan serta persalinan dan penyuluhan keluarga berencana. Pelayanan antenatal care memainkan peranan yang penting dalam mencegah dan mendeteksi komplikasi obstetrik sedini yang mungkin serta ditangani pada tahapan awal bagi mendapatkan ibu dan bayi yang sehat. Beberapa faktor yang mempengaruhi keaktifan ibu dalam melakukan kunjungan antenatal care yaitu umur, pendidikan, paritas dan pekerjaan (Lumongga, 2013)

Berdasarkan profil Kesehatan Indonesia tahun 2014 menunjukkan bahwa jumlah kunjungan K1 sebanyak 95,71\% atau 4.969 .467 ibu hamil, dan untuk Provinsi Jawa timur jumlah kunjungan K1 sebanyak 96,63\% atau 632.483. Berdasarkan hasil Riskesdas 2010 menunjukkan bahwa disparitas provinsi untuk akses Ibu hamil, terlihat provinsi DI Yogyakarta selalu menunjukkan cakupan terbaik: cakupan K1 100 persen, K1 ideal trimester 1 sebesar 91,5\%, dan K4 sebesar $89 \%$. Provinsi dengan cakupan K1 terendah adalah Papua Barat 71,3 \%. Untuk cakupan $\mathrm{K} 1$ ideal dan K4 terendah terjadi di provinsi Go- rontalo, masing-masing 25,9\% dan19,7 \%. Hasil penelitian yang dilakukan oleh Lumongga pada tahun 2013 terhadap 72 responden di Rumah Sakit Padang menunjukkan data bahwa jumlah ibu yang berpendidikan SD adalah 3 orang dan daripada jumlah tersebut hanya seorang ibu yang berpengetahuan baik tentang pemeriksaan antenatal. Sebanyak 21 orang dari pada 29 orang ibu yang berpendidikan SMP yang berpengetahuan baik dan hanya 8 orang yang tidak berpengetahuan baik tentang pemeriksaan antenatal. Jumlah ibu yang berpendidikan SMA adalah 32 orang dan daripada jumlah tersebut hanya 5 orang yang tidak berpengetahuan baik, 27 orang ibu berpengetahuan baik tentang antenatal care. Terdapat 6 orang ibu yang berpendidikan Perguruan Tinggi dan semua ibu tersebut termasuk dalam golongan tingkat pengetahuan baik tentang antenatal care. Ini menggambarkan bahwa semakin tinggi tingkat pendidikan ibu, semakin baik pengetahuannya tentang pemeriksaan awal kehamilan.

Hasil studi pendahuluan yang dilakukan pada tanggal 26 Sepetember 2015 di Puskesmas Krebet Kecamatan Pilangkenceng Kabupaten Madiun dengan metode wawancara pada $10 \mathrm{ibu}$ hamil yang melakukan pemeriksaan 2 orang berpendidikan dasar (20\%), 5 orang berpendidikan menegah $(50 \%)$ dan 3 orang berpendidikan tinggi $(30 \%)$.

Menurut Departemen Kesehatan RI (2007) tujuan pelayanan antenatal bagi ibu hamil adalah memantau kemajuan kehamilan untuk memastikan kesehatan ibu dan tumbuh kembang janin, meningkatkan dan mempertahankan kesehatan fisik, mental dan sosial ibu serta janin, mengenali secara dini adanya ketidaknormalan atau komplikasi yang mungkin terjadi selama hamil, 
termasuk riwayat penyakit secara umum, kebidanan dan pembedahan. mempersiapkan persalinan cukup bulan, melahirkan dengan selamat, ibu maupun bayinya mendapatkan trauma seminimal mungkin. Pendidikan kesehatan yang diberikan pada kehamilan tahap akhir menekankan pada persalinan dan proses melahirkan, Mempersiapkan ibu agar masa nifas berjalan normal dan pemberian ASI eksklusif. Mempersiapkan peran ibu dan keluarga dalam menerima kelahiran bayi agar dapat tumbuh kembang secara normal.

Menurut Lawrence Green (1980) dalam Notoatmodjo (2007) menganalisis perilaku pemanfaatan pelayanan kesehatan dipengaruhi oleh faktor perilaku (behavior causes) dan faktor di luar perilaku (non-behaviour causes). Perilaku itu sendiri terbentuk dari tiga faktor, salah satunya faktor predisposisi yaitu faktor pendidikan. Menurut Cahyani (2003) dalam Wahara (2012) bahwa dengan pendidikan tinggi maka seseorang akan cenderung untuk mendapatkan informasi, baik dari orang lain maupun media masa, semakin banyak informasi yang masuk, semakin banyak pula pengetahuan yang didapat tentang kesehatan. Dan menurut Hidayat (2005) dalam Wahara (2012) menyatakan bahwa pendidikan merupakan lembaga formal yang utama untuk memperoleh pengetahuan. Pendidikan merupakan penuntun manusia untuk berbuat dan mengisi kehidupannya yang dapat digunakan untuk mendapatkan informasi sehingga dapat meningkatkan kualitas hidup. Sebagaimana umumnya, semakin tinggi pendidikan seseorang makin mudah menerima informasi dan makin bagus pengetahuan yang dimilikinya. Sehingga dapat dinyatakan orang berpendidikan tinggi berpikir secara ilmiah, sehingga semua perilaku hidup termasuk dalam memberikan jawaban atas pertanyaan-pertanyaan tentang pentingnya pemerikaan kehamilan didasarkan pada logika, sedangkan orang yang berpendidikan rendah lebih cenderung kurang menggunakan logika berfikir sehingga banyak yang tidak diketahuinya tentang hal-hal yang bermanfaat jika melakukan pemerikaan kehamilan (Wahara, 2012).

Salah satu upaya mencegah terjadinya komplikasi selama masa kehamilan dan persalinan adalah dengan melakukan pemeriksaan kehamilan (antenatal care) secara teratur sesuai dengan standar. Cakupan kunjungan $\mathrm{K} 1$ dan $\mathrm{K} 4$ merupakan indikator keteraturan ibu hamil memeriksakan kehamilannya (Fauziyah, 2012). Diharapkan kepada pihak puskesmas supaya kegiatan kesadaran tentang pemeriksaan kehamilan ini harus lebih digiatkan lagi sehingga orang yang kurang berpendidikan juga boleh mendapatkan pengetahuan yang baik tentang antenatal care. Selain itu pada ibu hamil harus berusaha untuk mendapatkan informasi tentang pelayanan kehamilan sehingga dapat meningkatkan motivasi ibu dalam memeriksakan kehamilan dan lebih aktif dalam melakukan kunjungan pelayanan pemeriksaan kehamilan.

\section{METODE PENELITIAN}

Jenis Penelitian ini adalah observasional dengan menggunakan desain korelasional yaitu mengkaji hubungan antara tingkat pendidikan ibu dengan pemeriksaan awal kehamilan (K1) (Saryono, 2010) di Puskesmas Krebet Kecamatan Pilangkenceng Kabupaten Madiun. Penelitian ini menggunakan pendekatan cross sectional yaitu jenis penelitian yang menekankan pada waktu pengukuran/observasi data variabel independen dan dependen hanya satu kali, pada satu saat (Notoatmodjo, 2010). Jenis penelitian ini hanya meneliti tingkat pendidikan ibu dengan pemeriksaan awal kehamilaan (K1). Populasi penelitian ini adalah seluruh ibu hamil di Puskesmas Krebet Kecamatan Pilangkenceng Kabupaten Madiun pada Bulan Januari - Agustus 2016 sebanyak 49 ibu hamil. Sampel adalah bagian dari populasi terjangkau yang dapat dipergunakan sebagai subjek penelitian melalui sampling (Nursalam, 2008). Seluruh ibu hamil yang melakukan kunjungan K1 di Puskesmas Krebet Kecamatan Pilangkenceng Kabupaten Madiun pada Bulan Januari - Agustus 2016 sebanyak 49 
ibu hamil. Dalam penelitian ini, peneliti menggunakan teknik simple random sampling adalah bahwa setiap anggota unit dari populasi mempunyai kesempatan yang sama untuk diseleksi sebagai sampel (Notoatmodjo, 2010). Pada penelitian ini peneliti membuat gulungan kertas sesuai dengan nama masing-masing responden kemudian dilakukan pengundian secara lotre. Pada penelitian ini menggunakan uji statistik Wilcoxon Signed Rank.

\section{HASIL PENELITIAN}

\section{Data Umum}

a. Karakteristik responden berdasarkan usia (Tabel 1).

Tabel 1 menunjukkan bahwa sebagian besar responden berusia 20-35 tahun sebanyak 33 responden $(76,7 \%)$

b. Karakteristik responden berdasarkan pekerJaan (Tabel 2).

Berdasarkan Tabel 2 menunjukkan bahwa sebagian besar responden tidak bekerja yaitu sebanyak 26 responden $(60,5 \%)$.

c. Karakteristik responden berdasarkan jumlah Anak (Tabel 3).

Berdasarkan Tabel 3 menunjukan bahwa lebih dari setengahnya responden mempunyai anak 1 sebanyak 27 responden $(62,8 \%)$.

d. Karakteristik responden berdasarkan umur kehamilan (Tabel 4).

Berdasarkan Tabel 4 menunjukan bahwa hampir setengahnya responden mempunyai usia kehamilan 1 bulan dan 13-24 minggu sebanyak 30 responden $(69,8 \%)$.

\section{Data Khusus}

a. Tingkat Pendidikan (Tabel 5).

Berdasarkan Tabel 5 menunjukan bahwa sebagian besar responden paling banyak pendidikan responden adalah menegah (SLTA) sebanyak 29 responden $(67,4 \%)$.

b. Kunjungan ANC K1 (Tabel 6).

Tabel 1. Karakteristik Responden Berdasarkan Usia

\begin{tabular}{|c|c|c|c|}
\hline No & Usia & Frekuensi & Prosentase \\
\hline 1 & $<20$ tahun & 3 & $7,0 \%$ \\
\hline 2 & $20-35$ tahun & 33 & $76,7 \%$ \\
\hline 3 & $>35$ tahun & 7 & $16,3 \%$ \\
\hline \multicolumn{2}{|c|}{ Total } & 43 & $100 \%$ \\
\hline
\end{tabular}

Tabel 2. Karakteristik Responden Berdasarkan Pekerjaan

\begin{tabular}{|c|c|c|c|}
\hline No & Pekerjaan & Frekuensi & Prosentase \\
\hline 1 & Bekerja & 17 & $39,5 \%$ \\
\hline 2 & Tidak Bekerja & 26 & $60,5 \%$ \\
\hline \multicolumn{2}{|c|}{ Total } & 43 & $100 \%$ \\
\hline
\end{tabular}

Tabel 3. Karakteristik Responden Berdasarkan Jumlah Anak

\begin{tabular}{|c|c|c|c|}
\hline No & $\sum$ anak & Frekuensi & Prosentase \\
\hline 1 & 1 anak & 27 & $62,8 \%$ \\
\hline 2 & $2-3$ anak & 13 & $30,2 \%$ \\
\hline 3 & $>3$ anak & 3 & $7,0 \%$ \\
\hline \multicolumn{2}{r|}{ Total } & 43 & $100 \%$ \\
\hline
\end{tabular}

Tabel 4. Karakteristik Responden Berdasarkan Umur Kehamilan

\begin{tabular}{|c|c|c|c|}
\hline No & Usia kehamilan & Frekuensi & Prosentase \\
\hline 1 & $0-12$ minggu & 8 & $18,6 \%$ \\
\hline 2 & $13-24$ minggu & 30 & $69,8 \%$ \\
\hline 3 & $>24$ minggu & 5 & $11,6 \%$ \\
\hline \multicolumn{2}{r|}{ Total } & 43 & $100 \%$ \\
\hline
\end{tabular}


Tabel 5. Tingkat Pendidikan

\begin{tabular}{|c|c|c|c|}
\hline No & Pendidikan & Frekuensi & Prosentase \\
\hline 1 & Dasar (SD, SLTP) & 6 & 14,0 \\
\hline 2 & Menengah (SLTA) & 29 & 67,4 \\
\hline 3 & Tinggi (D3/PT) & 8 & 18,6 \\
\hline \multicolumn{2}{|c|}{ Total } & 43 & 100 \\
\hline
\end{tabular}

Tabel 6. Kunjungan ANC K1

\begin{tabular}{|c|c|c|c|}
\hline No & Kunjungan ANC K1 & Frekuensi & Prosentase \\
\hline 1 & K1 murni & 8 & 18,6 \\
\hline 2 & K1 akses & 35 & 81,4 \\
\hline \multicolumn{2}{r|}{ Total } & 43 & 100 \\
\hline
\end{tabular}

Tabel 7. Kunjungan ANC K1

\begin{tabular}{|c|c|c|c|c|c|c|}
\hline \multirow{2}{*}{ Pendidikan } & \multicolumn{4}{|c|}{ Kunjungan K1 } & \multicolumn{2}{|c|}{ Total } \\
\cline { 2 - 7 } & K1 murni & \multicolumn{1}{|c|}{ K1 akses } & \multicolumn{2}{|c|}{} \\
\cline { 2 - 7 } & $\mathrm{f}$ & $\%$ & $\mathrm{f}$ & $\%$ & $\mathrm{f}$ & $\%$ \\
\hline $\begin{array}{c}\text { Dasar } \\
\text { (SD,SLTP) }\end{array}$ & 0 & 0 & 6 & 14,0 & 6 & 14,0 \\
\hline $\begin{array}{c}\text { Menengah } \\
\text { (SLTA) }\end{array}$ & 0 & 0 & 29 & 67,4 & 29 & 67,4 \\
\hline $\begin{array}{c}\text { Tinggi } \\
\text { (D3, PT) }\end{array}$ & 8 & 18,6 & 0 & 0 & 8 & 18,6 \\
\hline Total & 8 & 18,6 & 35 & 81,4 & 43 & 100 \\
\hline
\end{tabular}

Tabel 6 menunjukkan bahwa sebagian besar responden melakukan kunjungan $\mathrm{K} 1$ akses sebanyak 35 responden $(81,4 \%)$ dan kunjungan K1 murni sebanyak 8 responden (18,6\%).

c. Hubungan pendidikan dengan kunjungan $\mathrm{K} 1$

Dari Tabel 7 hasil penelitian menunjukkan pendidikan tinggi (D3, PT) sebagian besar 8 responden $(18,6 \%)$ melakukan kunjungan K1 murni, untuk pendidikan menengah (SLTA) dan pendidikan dasar (SD, SLTP) seluruhnya melakukan kunjungan $\mathrm{K} 1$ akses masing-masing sebanyak 29 responden $(67,4)$ dan 6 responden $(14,0)$. Hasil statistic Wilcoxon Signed Rank pada program SPSS diperoleh hasil $\rho=0,042$. Jika $\alpha=0,05$ maka dapat disimpulkan $\rho<\alpha$ artinya $\mathrm{H}_{0}$ ditolak berarti ada hubungan antar tingkat pendidikan dengan pemeriksaan awal kehamilan (K1).

\section{PEMBAHASAN}

\section{Tingkat Pendidikan}

Berdasarkan Tabel 5 menunjukan bahwa sebagian besar responden paling banyak pendidikan responden adalah menegah (SLTA) sebanyak 29 responden $(67,4 \%)$.

Pendidikan merupakan faktor penting, stra- tegis dan determinatif bagi masyarakat. Maju mundurnya kualitas peradaban suatu masyarakat/ bangsa sangat bergantung pada bagaimana kualitas pendidikan di selenggarakan oleh masyarakat (Hariyanto, 2012). Pendidikan adalah suatu proses yang berarti dalam pendidikan itu terjadi proses pertumbuhan, perkembangan, atau perubahan ke arah yang lebih dewasa, lebih baik, dan lebih matang pada diri individu, kelompok atau masyarakat (Notoatmodjo, 2011).

Hasil penelitian ini menunjukkan bahwa sebagian besar responden pada penelitian banyak yang berpendidikan menengah (SLTA), hal ini dapat dipengaruhi banyak faktor dari lingkungan di daerah sekitar yaitu Individu yang berasal dari keluarga yang status ekonominya menengah dan tinggi dimungkinkan lebih memiliki pendidikan yang tinggi pula. Selain itu masih banyak pula anggapan masyarakt bahwa anak permpuan tidak perlu mencapai pendidikan yang tinggi, karena pada akhirnya nanti perempuan tidak dapat berkarir. Pendidikan yang tinggi sangat diperlukan bagi setiap orang karena dengan pendidikan yang tinggi akan lebih menerima segala informasi khususnya perempuan yang nantinya 
memerlukan banyak informasi saat hamil dalam melakukan pemeriksaan kehamilan ke tenaga kesehatan.

Tabel 1 menunjukkan bahwa sebagian besar responden berusia 20-35 tahun sebanyak 33 responden (76,7\%) dan Berdasarkan Tabel 4 menunjukkan bahwa sebagian besar responden tidak bekerja yaitu sebanyak 26 responden (60,5\%).

Usia adalah yang terhitung mulai saat dilahirkan sampai saat ia akan berulang tahun. Berbagai macam pendidikan atau sekolah dibatasi oleh umur. Sehingga umur mempengaruhi seseorang dalam mengakses pendidikan (Ahmadi, A dan Uhbiyati, 2001).

Menurut Suparyanto (2011) pekerjaan adalah serangkaian tugas atau kegiatan yang harus dilaksanakan atau diselesaikan oleh seseorang sesui dengan jabatan dtau profesi masing-masing. Status pekerjaan yang rendah mempengaruhi tingkat pendidikan seseorang.

Hasil penelitian ini menunjukkan bahwa usia dan pekerjaan merupakan faktor penting dalam pendidikan semakin tinggi usia semakin sulit untuk sesorang mengakses pendidikan dan semakin rendah status pekerjaan seseorang juga sebagian besar biasanya berlatar pendidikan yang rendah.

\section{Pemeriksaan Kehamilan atau Kunjungan ANC K1}

Tabel 6 menunjukan bahwa sebagian besar responden melakukan kunjungan $\mathrm{K} 1$ akses sebanyak 35 responden $(81,4 \%)$ dan kunjungan $\mathrm{K} 1$ murni sebanyak 8 responden $(18,6 \%)$.

Pemeriksaan kehamilan adalah suatu pemeriksaan yang dilakukan pada ibu hamil untuk mengetahui perkembangan kesehatan ibu dari mulai pertama hamil hingga menjelang persalinan (trimester III). (Rosli,2009). Pengertian pemeriksaan Antenatal Care yaitu: pemeriksaan ibu hamil untuk mengoptimalkan kesehatan mental dan fisik ibu hamil serta menyelamatkan ibu dan anak dalam kehamilan, persalinan dan masa nifas, sehingga keadaan post partum sehat dan normal serta persiapan pemberian ASI dan kembalinya kesehatan reproduksi secara wajar (Wardana, 2012).

Dijelaskan pula kepada ibu bahwa perlu dilakukan pemeriksaan kehamilan secara teratur makin tua kehamilannya makin cepat pemeriksaan harus diulang. Hal ini tergantung pula pada apa yang ditemukan pada pemeriksaan, umpamanya seorang wanita hamil dengan kelainan jantung, hipertensi atau diabetes mellitus, harus lebih sering diperiksa ulang daripada seseorang ibu yang sehat tanpa kelainan (Saifudin,2009).

Hasil penelitian banyak yang melakukan kunjungan K1 akses hal ini disebabkan kurang memahaminya ibu antara pemeriksaan kehamilan, semakin bertambahnya usia kehamilan ibu akan mengalami gejala kehamilan yang berbeda di setiap trimesternya oleh karena itu harus diimbangi dengan pemeriksaan yang rutin sebagai deteksi dini jika terdapat ganguan-gangguan kehamilan. Pemeriksaan kehamilan yang dilakukan ibu adalah minimal kurang dari 12 bulan sekali pada trimester pertama, sehingga dapat berlanjut pada trimester selanjutnya sampai ibu melahirkan.

Berdasarkan Tabel 3 menunjukan bahwa lebih dari setengahnya responden mempunyai anak 1 sebanyak 27 responden (62,8\%) dan berdasarkan Tabel 4 menunjukan bahwa hampir setengahnya responden mempunyai usia kehamilan 13-24 minggu sebanyak 30 responden (69,8\%).

Menurut Lowdermilk (2005), ibu yang menantikan kelahiran anak keduanya rasa kekwatiran yang berbeda pada masa kehamilan pertamanya dan tidak segembira pada saat melahirkan anak pertama. Sehingga untuk melakukan perawatan kehamilan juga berkurang. Biasanya tempat dan pertolongan melahirkan, para ibu hamil berpedoman pada kehamilan anak pertamanya. Respon ibu hamil tentang pemeriksaan kehamilan merupakan salah satu faktor yang mempengaruhi keteraturatan antenatal care. Adanya sikap lebih baik tentang antenatal care ini mencerminkan kepedulian ibu hamil terhadap kesehatan 
dirinya dan janin (Notoatmodjo, 2010).

Banyaknya anak dapat mempengaruhi kunjungan kehamilan biasanya ibu dengan pengalaman hamil pertama lebih khawatir tentang kondisi kehamilannya sehingga ibu akan melakukan pemeriksaan kehamilan serutin mungkin, begitu pula pada kehamilan yang usianya semakin bertambah ibu dengan hamil pertama akan lebih intensif dalam menjaga kehamilanya, sedangkan pada ibu hamil yang kesekian kalinya menganggap itu suatu hal yang biasa sehingga melakukan pemeriksaan kehamilan ketika disaat perlu melakukannya saja.

\section{Hubungan pendidikan dengan kunjungan K1}

Dari Tabel 6 hasil penelitian menunjukkan pendidikan tinggi (D3, PT) sebagian besar 8 responden $(18,6 \%)$ melakukan kunjungan K1 murni, untuk pendidikan menengah (SLTA) dan pendidikan dasar (SD, SLTP) seluruhnya melakukan kunjungan $\mathrm{K} 1$ akses masing-masing sebanyak 29 responden $(67,4)$ dan 6 responden $(14,0)$.

Hasil statistic Wilcoxon Signed Rank pada program SPSS diperoleh hasil $\rho=0,042$. Jika $\alpha=0,05$ maka dapat disimpulkan $\rho<\alpha$ artinya $\mathrm{H}_{0}$ ditolak berarti ada hubungan antar tingkat pendidikan dengan pemeriksaan awal kehamilan (K1).

Pada umumnya semakin tinggi pendidikan seseorang, semakin baik pula tingkat pengetahuannya (Notoatmodjo, 2007). Tingkat pendidikan yang tinggi berkaitan dengan pemahaman mengenai masalah kesehatan dan kehamilan yang mempengaruhi sikap terhadap kehamilan maupun dalam pemenuhan gizi selama kehamilan dan pelaksanaan kunjungan kehamilan. Orang berpendidikan tinggi berpikir secara ilmiah, sehingga semua perilaku hidup termasuk dalam memberikan jawaban atas pertanyaan-pertanyaan tentang pentingnya pemerikaan kehamilan didasarkan pada logika, sedangkan orang yang berpendidikan rendah lebih cenderung kurang menggunakan logika berfikir sehingga banyak yang tidak diketahuinya tentang hal-hal yang bermanfaat jika melakukan pemerikaan kehamilan (Wahara, 2012).

Berdasarkan hasil penelitian menunjukkan bahwa semakin tinggi tingkat pendidikan seseorang akan mempengaruhi kunjungan kehamilan yaitu responden yang berpendidikan tinggi cenderung melakukan kunjungan ANC K1 murni, sedangkan responden yang berpendidikan rendah cenderung memilih kunjungan ANC K1 akses. Sebenarnya banyak faktor yang mempengaruhi kunjungan ANC dari sini diperlukan peran suami dalam memotivasi istri untuk melakukan kunjungan kehamilan dengan rutin sesuai standart sehingga kesehatan ibu dan bayi akan lebih berkualitas dan diharapkan ibu juga dapat meningkatkan informasi yang diperoleh tentang kunjungan ANC sehingga dapat melakukan kunjungan dengan lebih aktif dan dapat mendeteksi kelainan pada kehamilan secara dini.

\section{KESIMPULAN}

\section{A. Simpulan}

1. Sebagian besar responden paling banyak pendidikan responden adalah menegah (SLTA) sebanyak 29 responden $(67,4 \%)$. Individu yang berasal dari keluarga yang status ekonominya menengah dan tinggi dimungkinkan lebih memiliki pendidikan yang tinggi pula.

2. Sebagian besar responden melakukan kunjungan $\mathrm{K} 1$ akses sebanyak 35 responden $(81,4 \%)$ dan kunjungan $\mathrm{K} 1$ murni sebanyak 8 responden $(18,6 \%)$. hal ini disebabkan kurang memahaminya ibu antara pemeriksaan kehamilan, semakin bertambahnya usia kehamilan ibu akan mengalami gejala kehamilan yang berbeda disetiap trimesternya.

3. Ada hubungan antara tingkat pendidikan dengan pemeriksaan awal kehamilan (K1) dari hasil uji statististik Wilcoxon Signed Rank pada program SPSS diperoleh hasil $\rho=0,042$. Jika $\alpha=0,05$ maka dapat disimpulkan $\rho<\alpha$ artinya $\mathrm{H}_{0}$ ditolak. semakin tinggi tingkat pendidikan seseorang akan mempengaruhi kunjungan keha- 
milan yaitu responden yang berpendidikan tinggi cenderung melakukan kunjungan ANC K1 murni, sedangkan responden yang berpendidikan rendah cenderung memilih kunjungan ANC K1 akses.

\section{B. Saran}

1. Bagi Responden (ibu Hamil)

Diharapkan dapat menambah pengetahuan mengenai antenatal care sehingga ibu hamil termotivasi untuk melakukan antenatal care secara teratur sebagai salah satu upaya mencegah terjadinya komplikasi kehamilan dan persalinan

2. Bagi Petugas Kesehatan

Diharapkan pada petugas kesehatan khususnya bidan dapat memberikan informasi selengkap mungkin untuk memotivasi kunjungan kehamilan sehingga meningkatkan target capaian yang digunakan serta dapat untuk meningkatkan layanan yang diberikan.

3. Bagi Intansi Pendidikan

Penelitian ini diharapkan dapat bermanfaat sebagai informasi untuk pengembangan kurikulum kebidanan khususnya keilmuan pelayanan pemeriksaan kehamilan.

4. Bagi Instansi Pelayanan Kesehatan

Diharapkan hasil penelitian ini dapat menjadi masukan dalam menentukan kebijakan program pelayanan pemeriksaan kehamilan sehing- ga dapat menerapkan program yang telah disepakati dengan baik.

\section{DAFTAR PUSTAKA}

Ahmadi A \& Uhbiyati (2001). Jenis Lembaga - Lembaga Pendidikan. http://alkhafy.blogspot.com/2008/11/jenis-lembagalembaga-pendidikan.html diakses tanggal 20 Oktober 2016

Depkes RI 2007. Profil Data Kesehatan Indonesia Tahun. http://www.kemenkes.go.id diakses tanggal 15 Oktober 2016

Fauziah (2012). Hubungan antara Intensitas Pemeriksaan Kehamilan Fasilitas Pelayanan Kesehatan dan Konsumsi tablet besi degan tingkat Keluhan Selama kehamilan.http://www. jurnalizidanpangan.ac.id diakses tanggal 23 Oktober 2016

Hariyanto (2012). Konsep Dasar Pendidikan. http://belajar psikologi.com/konsep-dasar-pendidikan/ diakses tanggal 21 Oktober 2016

Laudermik (2015). Pelaksanaan ANC Di Indonesia. http://www. dwi.wikipedia.co.id diakses tanggal 20 Oktober 2016

Lumongga. (2013). Hubungan Tingkat Pendidikan dengan tingkat Pengetahuan Tentang Antenatal Care Dalam Kalangan Ibu Usia Subur. Tersedia di http://www.repositoryusu.ac.id diakses tanggal 17 Oktober 2016

Notoatmodjo (2007). Promosi Kesehatan ilmu dan seni. Jakarta: Rineka Cipta

Notoatmodjo (2011). Promosi Kesehatan Teori dan Aplikasi. Jakarta: Rineka Cipta

Notoatmodjo. (2010). Metodologi Penelitian Kesehatan. Jakarta: Rineka Cipta

Nursalam (2008). Konsep dan Penerapan Metodologi Penelitian Ilmu Keperawatan. Jakarta : Salemba Medika

Rosli. (2009). Kehamilan Dan Permasalahannya. Jakarta: EGC

Saifudin (2009). Ilmu Kebidanan. Jakarta : Yayasan Bina Pustaka Sarwono Prawirohardjo

Saryono. (2010). Metodologi Penelitian Kebidanan. Yogyakarta: Nuha Medika

Suparyanto. (2011). Konsep Dasar Pendidikan. http://dr-suparyanto. blogspot.com $/ 2010 / 07 /$ konsep-pendidikan.html diakses tanggal 05 Oktober 2016

Wardana (2012). Konsep Kehamilan. http://cai-sl.blogspot.com/ 2012/07/konsep-dasar-pemeriksaan-kehamilan-atau.html Diakses tanggal 22 Oktober 2016 